\title{
Geospatial modelling of environmental and socioeconomic impacts of large- scale production of advanced biofuel
}

\author{
Obinna C.D. Anejionu ${ }^{\mathrm{a}, \mathrm{b}}$, Lorenzo Di Lucia ${ }^{\mathrm{a}}$, and Jeremy Woods ${ }^{\mathrm{a}}$ \\ ${ }^{a}$ Centre for Environmental Policy, Faculty of Natural Sciences, Imperial College London, South Kensington \\ Campus, London, United Kingdom. SW7 1NA \\ ${ }^{\mathrm{b}}$ Department of Geoinformatics and Surveying, University of Nigeria Nsukka, Enugu State, Nigeria
}

\begin{abstract}
Biofuels have become in many countries an alternative energy source for transportation. This has led to the construction of large-scale biofuel refineries. However, this process is raising concern among local stakeholders where the refineries are being sited. Here, we used geospatial techniques to implement a landscape design approach to address societal questions and local concerns regarding the impacts of introducing large-scale production of advanced biofuel (2G). Spatiallyexplicit landscape design was used to integrate various components in the biofuel supply chain and understand environmental and socioeconomic effects at various levels. Different techniques and modelling approaches were brought together with active participation of local stakeholders to provide answers to varying questions of community relevance. The application of the approach to the analysis of the case of cellulosic ethanol production from dedicated crops in Sardinia (Italy) shows that the introduction of a large-scale biofuel refinery could lead to positive outcomes at local level in terms of habitat quality, employment, energy production and reduction of GHG emissions. However, negative effects are expected regarding water availability and the production of food and animal feed in the landscape. This form of integrated knowledge about benefits and trade-offs can be used by project developers and policymakers to steer the deployment of biofuel projects to advance high level policy goals while respecting local priorities and concerns.
\end{abstract}

Keywords: Integrated Assessment, Biofuel, Biorefineries, Geospatial Modelling, Landscape Design 


\section{Introduction}

Overwhelming concern on the effects of continuous use of fossil fuel on the world's climate is driving increasing interests in the use of biofuels such as bioethanol, biogas and biodiesel as alternative energy sources for transport [1-5]. For many countries, biofuel utilisation is seen as a key strategy to reduce carbon emissions in transport and improve the local economy by minimising dependency on imported hydrocarbon fuel [6]. As a result, several bio refineries have sprung up across Europe and other parts of the world such as Inbicon in Denmark, Abengoa in Spain and Süd-Chemie AG in Germany, Andeavour in the United States $[1,7,8]$.

However, the switch towards biofuels is not without implications to the environment, social, political and economic aspects of the society [9-13]. In the past decades, biofuel production has employed primarily first generation $(1 \mathrm{G})$ technologies, which rely on food crops such as sugar cane, grains, starch and vegetable oils [14]. However, numerous studies have reported limited energy balance combined with limited GHG savings over the entire lifecycle, especially when indirect emissions are accounted for $[6,14,15]$. In addition, $1 \mathrm{G}$ technologies have been found to lead to increased competition for fertile land (directly or indirectly) resulting in the conversion of natural areas and the release of the carbon stored in the soil and biomass [16].

The inability of $1 \mathrm{G}$ biofuel technologies to address all these concerns has led to the development of advanced $(2 \mathrm{G})$ technologies that utilise residues from agriculture and forestry such as wheat straw, corn stover, and sugarcane bagasse, or dedicated energy crops such as miscanthus and short rotation coppice (SRC) to produce biofuel [1,14,17-19]. Deployment of 2G biofuel technologies minimise competition for fertile agricultural land compared to $1 \mathrm{G}$ technologies, through the utilisation of rapidly growing perennial grasses, which can grow on marginal lands, and residues from forests and food crop production [20,21]. 2G technologies can achieve savings of GHG emissions up to $95 \%$ [22] and higher material and chemical efficiencies compared to $1 \mathrm{G}$ 
technologies $[23,24]$. Hence, governments are increasingly supporting research, development and deployment of $2 \mathrm{G}$ technologies [17,22].

Despite these potentials, large-scale deployment of $2 \mathrm{G}$ technologies is progressing at a much slower pace than hoped for [7], due to the combined effect of low oil prices, policy uncertainty, local perception of impacts, feedstock supply challenges and high production costs $[17,25]$. In particular, the perception of social and environmental impacts, and the associated policy uncertainty have become critical challenges with a wide range of concerns linked to the introduction of large-scale projects, especially in predominantly rural communities. Such largescale activities could accelerate or disrupt certain activities in the short, medium and long run. Thus, their introduction can be facilitated by a systemic understanding of the potential impacts on land use, water availability and quality, soils and biodiversity, as well as on food production systems, employment, rural development, etc. The breath and intensity of potential impacts justify the use of modelling to analyse the interactions that could arise in a landscape as result of the largescale projects. Tackling such wide-ranging concerns requires a combination of various approaches, which geospatial techniques could help bring together for accurate analysis. Following this line of thinking, the aim of this research was to apply a spatially-explicit landscape design approach suitable to assess the potential benefits and trade-offs generated by the introduction of a biorefinery, on the use of environmental resources, local livelihood and the economy of the study area.

\subsection{Implementing landscape design with GIS}

Biofuel systems have a wide range of complex ecological and socioeconomic effects often operating over broad spatiotemporal scales [26]. It has been suggested that a beneficial implementation of bioenergy and biofuel projects could be facilitated by the application of a landscape design approach [27]. Here landscape design is interpreted as a spatially explicit and collaborative plan for management of landscapes and supply chains. By adopting a systems 
perspective, which takes into account every aspect of the biofuel system (including ecological and socioeconomic), to account for spatial heterogeneity and the influences of a particular situation, with full involvement of stakeholders [28,29], landscape design can be used to integrate bioenergy production with other components of the society (environmental, social and economic). This could help address the interactions arising at multiple scales. Successful implementation of biofuel projects could be facilitated if pre-emptive landscape design processes were employed to identify and address concerns before they become a problem, thereby reducing unforeseen project outcomes and promoting public support [27]. A critical challenge is that biofuel production is likely to generate a wide range of trade-offs and benefits [30] and landscape design requires knowledge about the current distribution of ecosystem and societal services, potential winners and losers, as well as perceived needs and expectations of stakeholders in relation to these services. Geographic Information System (GIS) presents a robust and practical way of developing the knowledge needed for landscape design, due to its power to integrate, manage and analyse information from a wide range of sources [31]. Increased deployment of GIS techniques in landscape design research was advocated by [32], who outlined various application areas such as in spatial estimation and applications for bioenergy, where it has been underutilised. In this research, we deployed GIS techniques alongside other analytical and modelling tools such as Soil and Water Assessment Tool (SWAT), Integrated Valuation of Ecosystem Services and Trade-offs (InVEST) and Linkage Mapper, to develop landscape knowledge suitable to support decisionmaking.

\subsection{The biofuel project in Sardinia}

Following the successful completion of a pilot plant in the North of Italy, Biochemtex (previously a petrochemical company), initiated a project to build a large-scale plant for commercial production of cellulosic ethanol in the region of Sardinia $[33,34]$. The site selected for the industrial plant was a brownfield (land previously used for industrial purposes that has become vacant and 
contaminated), located in the south-west of Sardinia (Figure 1). The large and decaying industrial complex, provided industrial symbiotic advantages. The high levels of pollution, caused by previous industrial and mining activities, and high unemployment resulting from the closure of these very same activities $[34,35]$ meant that the project received the endorsement of the Italian national government for its potential contribution to a "green industrial development" in the region [34].

The biofuel project was planned to have an industrial capacity of 80,000 tons of ethanol and circa 180,000 Dry Matter (DM) tons of lignin per year (to be co-fired at a local coal power plant), from the processing of c.430,000DM tons of biomass. The feedstocks selected for the project were agricultural residues (cereal straw) and dedicated crops in the form of locally produced giant reed (Arundo donax) cultivated within a maximum distance of $75 \mathrm{~km}$ from the biofuel plant [36]. Giant reed was considered a promising crop for large-scale production of bioenergy in the study area [37]. Local field trials showed that when not constrained by water limitations, giant reed could provide yields between 25 and 35DM tons per ha [38]. Based on these yields, between 5200 and 7200 ha of arable land would be needed to provide the required c. $180,000 \mathrm{DM}$ tons/year, or $41.3 \%$ of the biomass feedstock required by the project. The year 2011 was selected as the reference year to simulate the implementation of the Biochemtex project in Sardinia.

\section{Study Area}

Assessment in this study was conducted at watershed level. The watershed, located in the southwest of the island of Sardinia (Figure 1), was delineated based on the features of the biofuel supply chains (illustrated in Section 1.2). The study area is characterised by a semi-arid and dry sub-humid climate with annual mean temperature of $16^{\circ} \mathrm{C}$. This largely agricultural area is dominated by arable crops and animal farming with an average annual rainfall range of $550-$ 
$600 \mathrm{~mm}$. The terrain is largely flat and undulating, extending from the coastline with elevation in the range of $1-460 \mathrm{~m}$ above the sea level [37].

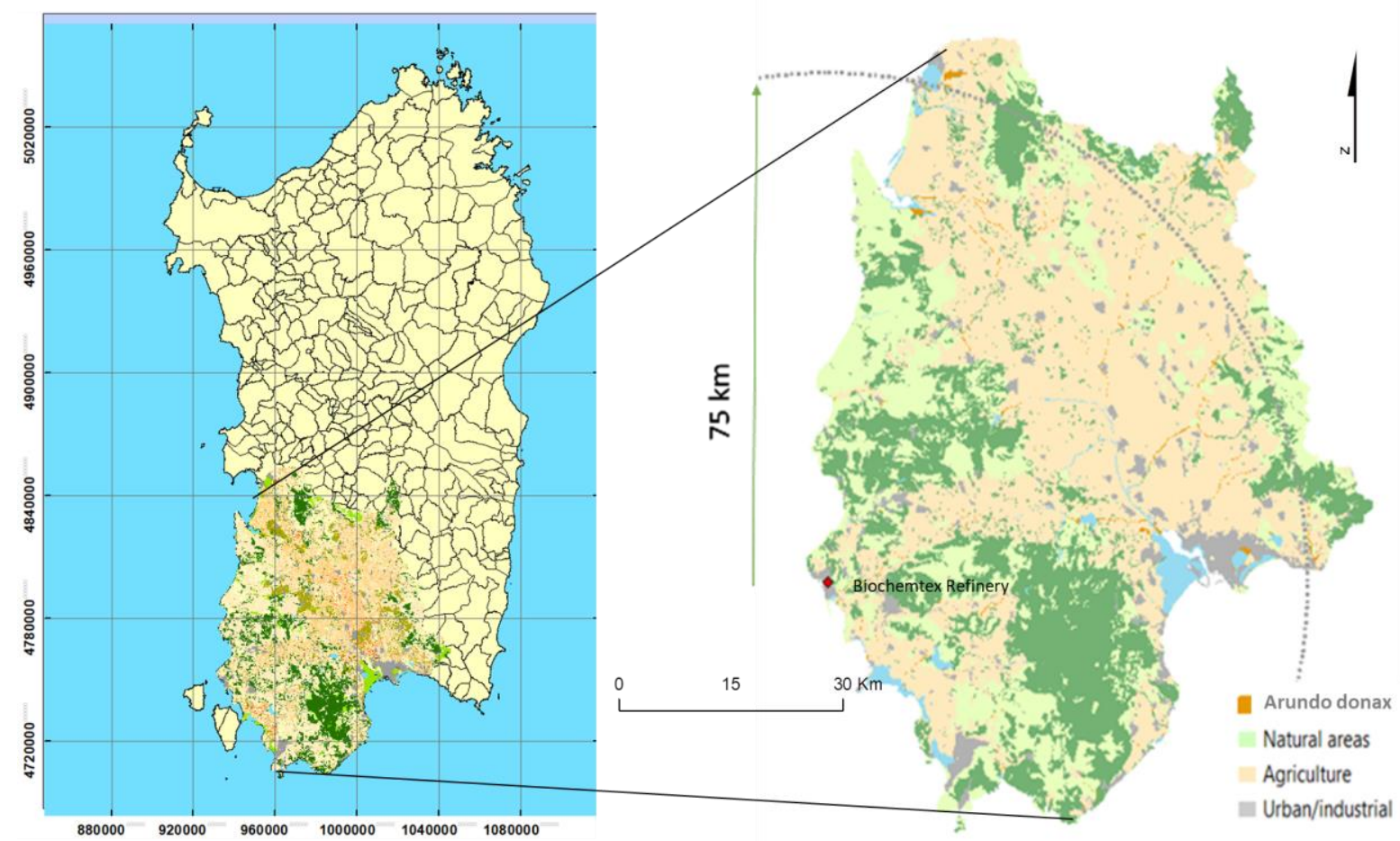

Figure 1. Map of the island of Sardinia and the study area.

\section{Methodology}

\subsection{Data}

The following spatial and non-spatial datasets were used in this project. An ASTER digital elevation model (DEM) of the study area obtained from NASA Reverb Echo (now EarthData platform) [39] was used to derive topographic information. CORINE for 2012 containing 44 land cover classes across Europe, obtained from the Copernicus Land Monitoring Services [40] was used to derive the land use map. A spatial dataset containing details of crops grown in the area in 2008 was obtained from the Regional Agency for Agricultural and Rural Development (LAORE) [41]. Soil data was retrieved from the regional database Sardia Geoportal [42].

Livestock data was obtained from the National Office of Statistics [43], while data of farming practices, including operation schedules, was obtained through interaction with stakeholders including local farming associations and experts from LAORE. Weather data was obtained from 
the WorldClim [44] and a map of irrigation areas obtained from the Council for Agricultural Research and Economics [45]. In addition, a spatial dataset containing information on population was obtained from the National Institute of Statistics [43].

\subsection{Processing of CORINE Land Cover (CLC)}

CORINE Land Cover (CLC) was used to derive the LULC map for this study [40]. We employed CORINE to characterise natural areas without further refinement, because it was the most comprehensive and accurate dataset available for Sardinia. However, we did not find it appropriate for the delineation of agricultural areas as it contained only two categories of agricultural land intensively and extensively cultivated. Hence, the CORINE map was reprocessed using the map of irrigation systems [45], knowledge of local experts and the dataset of cropland provided by LAORE [41], the improve its level of detail. Map of irrigation systems was used to spatially characterise crops that required irrigation, e.g. maize, alfalfa, etc., while expert knowledge, collected through interviews, allowed further characterisation of agricultural areas both within and outside the irrigation systems. For instance, experts indicated that horticultural crops were present primarily in the 'Sardegna Meridionale' irrigation system, near the capital of the region (Cagliari), while there was no production in the 'Oristano' irrigation system. The refined dataset of LULC was merged with the highly detailed data for cropland provided by LAORE [41]. This labour intensive and time-consuming process improved the quality and accuracy of the dataset. However, when validated against statistical data of crop areas from the National Statistical Office [43], the LULC dataset presented a range of minor inconsistencies, i.e. missing acreage for some crops. Such inconsistencies were addressed by allocating crop areas to suitable lands through a GIS "random" procedure with the software ArcGIS. Figure 2 displays the map of LULC developed through this process and employed in this study. 


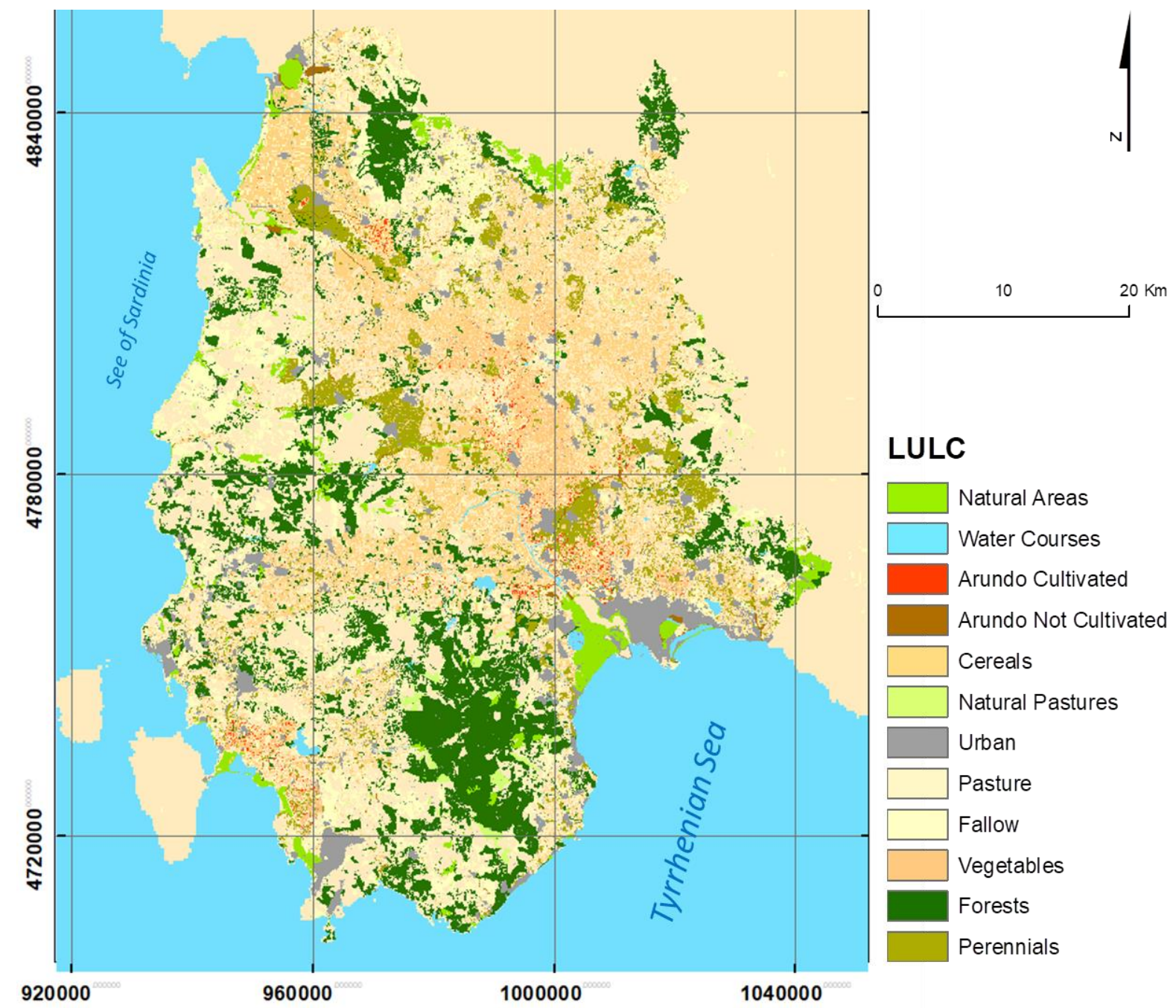

Figure 2. Map of land use and land cover employed in the study area.

\subsection{Brief description of models deployed}

Three key GIS-based models namely: Soil and Water Assessment Tool (SWAT), Integrated Valuation of Ecosystem Services and Tradeoffs (InVEST) and Linkage Mapper, were deployed in this study. The models were employed to simulate different aspects of the landscape and assess the effects of land use change generated by the biofuel project. Key aspects of the models are briefly presented in the following sections.

\subsubsection{SWAT}

The SWAT model was developed to predict the impact of management practices on water, sediment, and agricultural chemical yields in large, complex watersheds with varying soils, land use, and management conditions over long periods of time at the watershed/river basin level [46]. 
It has been widely applied to assess regional soil and water quality, and sediment transport, and nutrient loading [47-52], nutrient loading from dairy waste application areas, waste treatment plants, urban areas, conventional row crops and rangeland. Extended review of SWAT and its applications was undertaken by [52]. The ArcSWAT 10.19, which is the ArcGIS extension with graphical user interface, was used in this study.

\subsubsection{InVEST}

InVEST is a suite of models that is used to quantify and map the value of ecosystem services $[53,54]$. It was designed to inform decisions about natural resource management by providing information on how changes in the ecosystems could result in changes in benefits flowing to people. Its provides an effective tool for exploring the likely outcomes of alternative management and climate scenarios and for evaluating trade-offs among sectors and services [53]. It is amenable to a GIS environment because its models are spatially explicit. InVEST has been applied to model ecosystem services in various parts of the world by the Natural Capital Project $[53,55]$.

\subsubsection{Linkage Mapper}

The Linkage Mapper is a GIS based connectivity analysis software, which applies circuit-theory to connectivity analyses at landscape level [56]. It consists of tools used to automatically identify and map linkages between habitat areas. Employing spatial datasets of core habitat areas and resistances, landscapes are mapped as grids of raster cells representing varying qualities of habitat, dispersal routes, or movement barriers. These qualities are analysed using circuit theory to predict different aspects of connectivity and movement probabilities [57].

\subsection{Methods}

This study involved a combination of GIS-based modelling techniques with active stakeholders' participation to understand the diverse ways large-scale biofuel production could affect a landscape. Interactions with local stakeholders were used to identify local concerns and 
expectations. These concerns and expectations were subsequently used to identify key indicators for the analysis of different scenarios for the biofuel refinery. The key stages of this research involved the identification of concerns and expectations of stakeholders in the area, the selection of the analytical tools, the delineation of the watershed of interest, the development of biofuel scenarios to simulate potential changes that may result from the biofuel activities in the landscape, the identification of impact indicators, the evaluation of impacts on key indicators and the validation of modelling outputs with stakeholders during stakeholder workshops. Many of the interactive activities conducted throughout this process relied on the web interface developed for this project (Section 3.7) to enhance communication with stakeholders and allow users to evaluate the analyses and contribute to their quality.

\subsubsection{Analysis and engagement of local stakeholders}

To facilitate consensus building and improve the awareness and the participation of locals that are potentially affected by the introduction of the biorefinery, key individuals and organisations were identified as stakeholders. A review of the media coverage and written sources suggested that the biofuel project was widely discussed in the area with a wealth of views against its implementation and a small number in favour. We identified a set of ten categories of key groups of stakeholders including farmers, regional and local governments, NGOs, research institutions and the biofuel company. The early involvement of stakeholders in the research process was to ensure that they were properly informed, participated actively in the analyses, and had the opportunity to make contributions, such as challenge the status quo and assumptions.

Representatives of the stakeholder groups were engaged first through in-person interviews to evaluate their knowledge of the biofuel project and their views and attitudes toward the project. Here we present the main results and some of the critical issues identified through the interviews (further details are provided by [58]). 
The analysis showed that stakeholders overall, had a limited knowledge of the biofuel project. This is due to the communication strategy adopted by the biofuel company, which sought to keep the project 'out of the spotlight' [36]. Several stakeholders were not able to illustrate the basic features of the biofuel project, while others showed a high level of misinformation. For instance, a representative of a local NGO assumed that the cultivation of giant reed was planned to cover a large, contiguous area of several thousand hectares. Similarly, a representative of the Regional Agricultural Agency feared the project would lead to the conversion of traditional vineyards. The interviews provided data gave insights into local views and attitudes toward the project (Table 1). During the interviews, participants were asked to identify the expected effects of the project both positive (opportunities) and negative (threats) on society and the natural environment. The importance of each issue was then characterised on a scale from 1 (least important) to 5 (vital) depending on the number of times the issue was mentioned by the interviewee and how significant the impact of the biofuel project was expected to be. Blank cells in Table 1 indicate that an issue was not mentioned by the interviewees. The results show a range of recurrent threats to, e.g. the availability of water for irrigation, local food production, biodiversity and the production of animal feed. Among the opportunities identified were generation of income and employment, reduction of GHG emissions, improvement of water quality, and provision of energy. The issue of soil quality represented a contested case due to differences in the knowledge and interest of the stakeholders. For example, while farmers and their associations perceived it as a threat due to the problems connected to the removal of giant reed at the end of the growth cycle, the regional government and NGOs focused on the opportunities of using polluted land for giant reed cultivation. Among the issues that received less attention, i.e. large number of blank cells in Table 1, were those related to energy provision (one entry), water quality, climate change mitigation and animal feed production (two entries each). Opportunities are displayed in striped colour (green); threats are in plain colour (red). 
Table 1. Stakeholder perceptions of the effects of the biofuel project in the landscape.

\subsubsection{Delineation of the landscape and multi criteria evaluation}

Biofuel systems span across and affect multiple spatiotemporal scales; thus, the definition of the spatial, social and ecological boundaries was critical in understanding their impact. This study combined the Ecosystem Services (ES) framework with the supply chain assessment to define the boundaries of the biofuel system. The boundaries were defined by spatially locating the biofuel supply chain (from feedstock growing to biofuel production). Hence, the spatial extent of the ecosystem services and functions affected by the supply chain (the landscape, see Figure 1) were delineated based on the framework.

GIS multi-criteria evaluation was deployed at this stage to identify lands suitable for the growing of feedstock for biofuel production within the watershed. The criteria used were selected based on information obtained from representatives of the biofuel company. An area was considered suitable for feedstock cultivation if it satisfied the following conditions: (i) lay within a $75 \mathrm{~km}$ from the biofuel plant; (ii) not used for production of food crops; (iii) serviced by an irrigation network; and (iv) a minimum size of 0.5 ha [36].

Our field investigations in the catchment area revealed that most lands not used for cultivation of food crops were used for sheep grazing. These were targeted as lands suitable for growing giant 
reed for biofuel production. GIS techniques were used to select these lands and the resulting data was reclassified into a binary dataset, showing areas used for grazing in one class, and the rest in another class.

\subsubsection{Development of scenarios}

Various alternative scenarios that could be deployed to support the biorefinery were developed and modelled. The in-situ landscape in 2011 was used as the baseline scenario, while four alternative biofuel scenarios of land use and natural resource management were developed based on stakeholders' inputs. The following are the key features of the scenarios:

1. Baseline scenario - in this scenario no biofuel is produced and, thus, no giant reed is cultivated in the catchment area.

2. Company scenario - this scenario is in line with the business plan of the biofuel project as drafted by the investor. Here giant reed is cultivated over an area of c.6000ha of arable land previously used for animal grazing and irrigated with water supplied by the irrigation system.

3. Recycled Water scenario - in this scenario, the impact of the biofuel project on the availability of water resources in the landscape is mitigated by irrigating the giant reed with water recycled at four water treatment plants in the area.

4. Polluted Land scenario - to mitigate the project impacts on agricultural production in this scenario giant reed is cultivated on land officially classified as contaminated due to industrial or mining activities [59].

5. Food and Fuel scenario - in this scenario, $30 \%$ of the 180,000 tons of giant reed required in the Company scenario is substituted with cereal straw supplied by increasing the acreage of durum wheat in the catchment area. The remaining share of the biofuel feedstock is provided as giant reed in line with the Company scenario. 
A critical feature of all the scenarios is that farmers are assumed to be willing to cultivate giant the biofuel investor, we consider the assumption appropriate in light of the aim of the study. Insights on these issues emerged from the economic analysis (Section 4.5)

\subsubsection{Identification of indicators}

Inputs provided by stakeholders with regards to values and concerns linked to the biofuel project were used to select the modelling tools, the key indicators and appropriate spatial and temporal scales for the analysis. Factors originating outside the study area with the potential to significantly influence the ecosystem services of interest in the landscape, or the biofuel supply chain were accounted for. These included (national and EU) policies and economic factors pertaining to climate change mitigation, renewable energy deployment, agriculture and food security. Based on this, a set of indicators were selected to measure impact on water resources, biodiversity, provision of energy, food and animal feed, emissions of GHG, and employment and income generation (Table 2).

\subsection{Spatial modelling of the scenarios}

To simulate the alternative scenarios, various GIS and modelling techniques were deployed. Techniques such as multi criteria evaluation, reclassification, buffering, overlay, resampling, map algebra were used to reprocess the datasets before they were used in the modelling and analysis. In the process, the land use data was modified to reflect the changes in each scenario (Figure 3). 

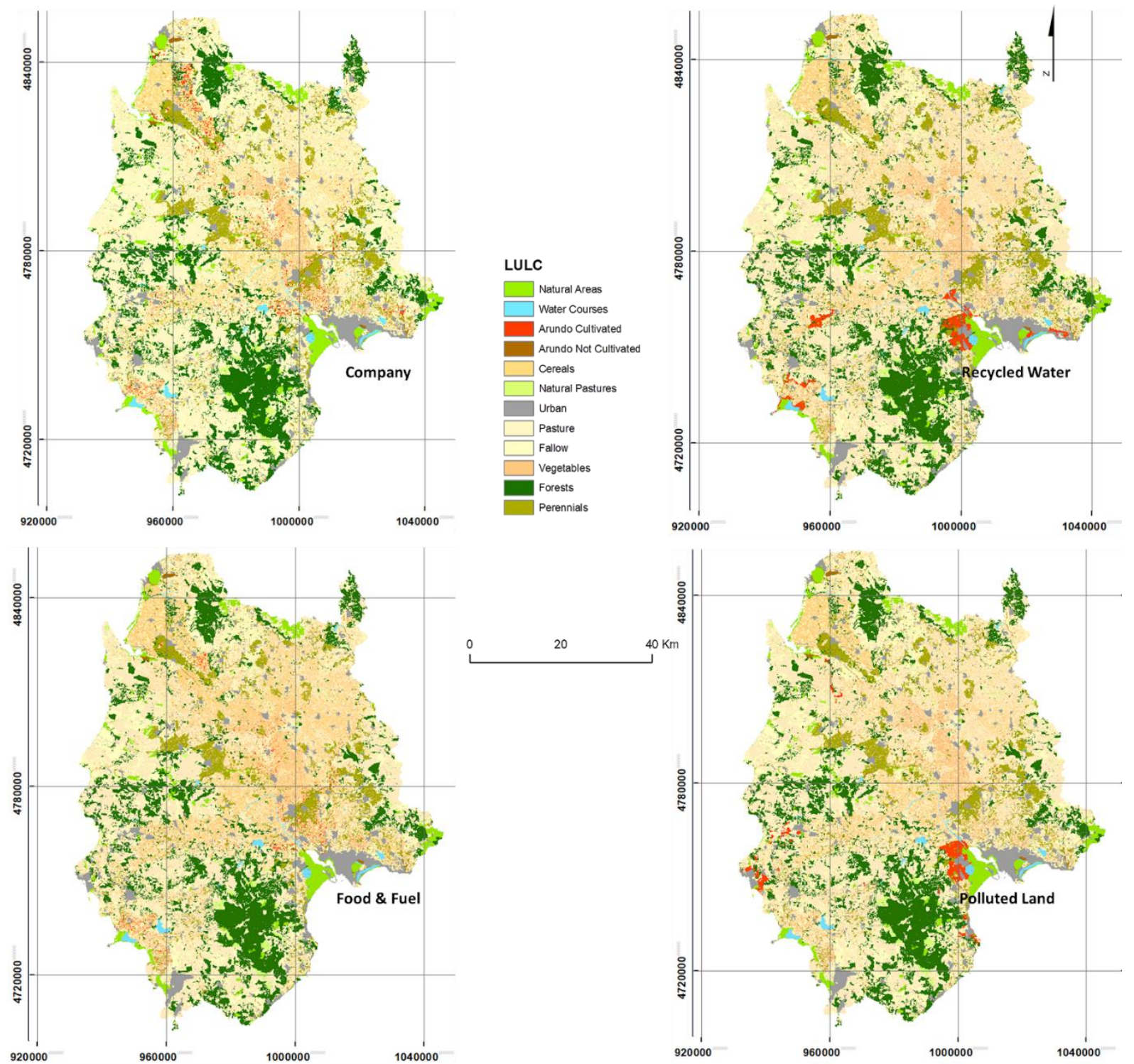

Figure 3. Land use and land cover for the four alternative scenarios derived using multi-criteria evaluation.

In the analysis of each scenario, SWAT was used to model water consumption and availability, and the production of food crops and animal feed including graze biomass. InVEST and Linkage Mapper were used to evaluate impacts on biodiversity, considering habitat quality and connectivity. In addition to these GIS-based models, we developed a set of area-based models (illustrated in Section 3.6) to analyse the effects of each scenario on the provision of food, animal feed and energy as well as the emissions of GHG and the generation of employment and income in the study area. 


\subsubsection{SWAT Modelling}

Water related processes were modelled with SWAT employing land use, digital elevation model and soil data as basic spatial inputs for the modelling. The model operates by partitioning the watershed into smaller subunits namely: subbasins and Hydrologic Response Units (HRU). The HRU are the portions of a subbasin with a unique combination of land use, soil and management attributes. The modelling process involves the delineation of the hydrologic watershed and stream network, definition of the HRUs and subareas, which involves the overlay of the land use, soil and elevation data in order to create HRUs. Subsequently, the HRUs are combined with weather data and other relevant information such as farming operation management schedules, fertilizer applications, and number of herds used to simulate a particular scenario [46]. Details of the SWAT modelling are reported in a separate forthcoming report.

\subsubsection{InVEST Modelling of habitat quality}

The biodiversity model assumed that land use changes occasioned by large-scale production of biomass could affect the biodiversity of the area [60]. Whereas a variety of approaches have been suggested for assessing biodiversity at landscape level, this study used two factors: habitat quality and habitat connectivity, as proxies of the status of biodiversity. Habitat quality was assessed using the habitat quality model InVEST. In InVEST, the quality of each patch of habitat is a function of: (a) the inherent value of the habitat, (b) distance from threats (i.e. all land uses that are not habitat such as roads, urban areas, etc.), (c) threat's relative impact (relative sensitivity of each habitat type to each threat), and (d) degree to which the land is legally protected, or physically inaccessible. Thus, areas with a higher quality of habitat, support higher levels of biodiversity compared to that of areas with lower habitat quality.

Based on a review of the scientific literature and interviews with local experts, various categories of habitats were identified and classified. Natural land, including forests, natural grassland and rangeland, wetlands, etc. were classified as high-quality habitat, and assigned with a value of 1 . 
Forest plantations and perennial crops including giant reed were classified as medium quality habitat (with a value of 0.5 ). Fruit trees, olives and grapes were grouped into lower quality habitat (value of 0.3 ). All other land uses were classified as threats to habitat quality. The impacts of threats were simulated considering their geographical location, a maximum distance interval, habitat sensitivity to each type of threats, and habitat accessibility. The model output is a unit-less value representing the sum of the habitat quality of all parcels in the study area.

\subsubsection{Linkage Mapper modelling of connectivity}

The Linkage Mapper was used to assess the habitat connectivity of the study area. Spatial datasets of core habitat areas and resistances were used to identify and map linkages between core areas. The LULC for each scenario was reclassified to create habitat core areas and a resistance map, based on resistance values obtained from consultation with local stakeholders and scientific literature. Cells in the resistance dataset were attributed with values reflecting the energetic cost, difficulty, or mortality risk of moving across that cell. Land covers such as arable lands, roads, and built environment were assigned high resistance values while grazing land had lower value. As animals move away from specific core areas, cost-weighted distance analyses produce maps of total movement resistance accumulated [56]. Habitat connectivity is subsequently determined by identifying adjacent habitat core areas and creating maps of least-cost pathways (LCP) between them. The final results show the relative value of each cell in providing connectivity between core areas. This dataset is used to identify the features that affect (facilitate or impede) movement between core areas [56].

\subsection{Non-spatial modelling}

Non-spatial approaches were deployed to assess the effects of the biofuel project on issues considered important by local stakeholders including the availability of locally produced food, 
animal feed and energy (heat, electricity and transport fuels), and the generation of employment, income and GHG emissions.

For the assessment of issues related to food, feed and energy, we developed a set of area-based mass balance models in which spatially-explicit data was employed to estimate the effects of the biofuel project. Mass balance models are widely used in engineering and environmental analyses to identify mass flows accounting for material entering and leaving a system, based on assumption that matter cannot disappear or be created spontaneously. In our study, we applied a two-stage approach combining empirical and spatial information to assess the baseline and the four biofuel scenarios. The food mass balance examined the effects of giant reed cultivation on the production and availability of food in the landscape. Competition with food production is one of the key concerns of large-scale deployment of biofuel. We computed total food production in the catchment area accounting for (i) meat, milk and dairy products using official farm-level statistics of livestock volumes and productivity for Sardinia [61], and (ii) crops, fruits and vegetables based on the outputs of SWAT model simulations. Total food production was converted into Kcal and compared against total food consumption computed based on (a) 2011 population levels (assumed to be constant throughout the simulation period) and (b) food intake per person based on FAO "food balance sheets" for Italy.

A similar approach was applied to estimate the area-based mass balance of the animal feed sector. The cultivation of dedicated crops for biofuel production can compete with animal feed production through competition for land resources. Feed consumption in the study area was estimated based on regional statistics, while production volumes were an output of SWAT simulations. Total feed production (in Forage Units) for each scenario was simulated and total feed consumption for the main categories of livestock (cow, sheep, goat and swine) was calculated based on (i) livestock population (assumed constant for the period of interest), (ii) information on daily feed intake coefficients obtained from regional statistic and (iii) expert consultations [62]. 
Finally, we developed a mass balance model for the energy sector in the study area. The contribution of biofuels to energy provision is a primary reason for the construction of a biofuel refinery. For each scenario, we estimated local energy availability as the difference between demand and supply of energy products. Demand comprised the consumption of energy (in MWh) for transport activities (rail and road), heating and electricity within the landscape. Energy supply was computed based on information from the biofuel company and official regional statistics. In particular, the assessment calculated the share of local energy sources (wind, solar, hydro, biomass and coal) on the total amount of the energy supplied.

Another key driver of biofuel deployment is climate change mitigation through a reduction of transport-related GHG emissions. The calculation of GHG savings is traditionally conducted applying Life Cycle Assessment (LCA) methodologies, which assess the emissions generated by the supply of a ton or MJ of ethanol. In this study, we conducted an LCA of giant reed ethanol in the study area and developed an area-based inventory of all GHG emissions related to the energy (electricity, heat and transport) and agricultural (exclusively animal farming) sectors. GHG emissions of animal farming activities were estimated using IPCC [63] guidelines as tons of $\mathrm{CO} 2$ eq per year. In the process, livestock consistencies were obtained from regional statistics [61], while animal emission factors were calculated in line with Tier 3 methods for cattle and sheep, and Tier 1 methods for swine and goat from IPCC [63]. Similarly, the inventory of energy based GHG emissions was conducted applying [63] considering energy consumed for transport, heat and electricity (including grid losses).

Employment and income generation, two key drivers that attract local support for biofuel projects, were also evaluated. The contribution of the biofuel project to direct employment was estimated as Full Time Employment (FTE) using data obtained from the biofuel company, ancillary information from scientific literature (transport and industrial activities) and regional values for labour demand as man hour per hectares of crops cultivated in the area [64]. 
Finally, the project contribution to economic development of rural areas was estimated considering

the generation of additional incomes as additional net cash income at farm and landscape level. In the analysis, we calculated the breakeven point curve of giant reed considering expected yields (t/ha) obtained from local field trials [38] and market prices of giant reed. Breakeven values at farm level were subsequently used to calculate giant reed net cash income in the catchment area.

A summary of the modelling components is presented in Table 2.

Table 2. Details of models used for the integrated analysis

\begin{tabular}{|c|c|c|c|}
\hline \multicolumn{2}{|c|}{ Issue - indicator and unit } & Model & Description \\
\hline \multicolumn{2}{|c|}{ Water availability $-\mathrm{m} 3 / \mathrm{y}$} & $\begin{array}{l}\text { Soil and Water } \\
\text { Assessment Tool } \\
\text { (SWAT) }\end{array}$ & $\begin{array}{l}\text { Examines and simulates the consumption of } \\
\text { irrigation water used for giant reed, and the } \\
\text { availability of water in reservoirs }\end{array}$ \\
\hline \multirow[t]{2}{*}{ Habitat } & Quality - n.a. & InVEST model & $\begin{array}{l}\text { Examines and simulates the impact of land use } \\
\text { changes on habitat quality as an indicator of } \\
\text { biodiversity at landscape level }\end{array}$ \\
\hline & $\begin{array}{l}\text { Connectivity - } \\
\text { number of } \\
\text { links }\end{array}$ & Linkage Mapper model & $\begin{array}{l}\text { Examines and simulates landscape connectivity } \\
\text { measured as Least Cost Path between habitat } \\
\text { patches }\end{array}$ \\
\hline \multicolumn{2}{|c|}{ Food production $-\mathrm{Kcal} / \mathrm{y}$} & $\begin{array}{l}\text { Area mass balance - } \\
\text { Spreadsheet }\end{array}$ & $\begin{array}{l}\text { Examines and simulates food consumption and } \\
\text { production in the landscape. Consumption is from } \\
\text { FAO national "food balance sheets"; production is } \\
\text { from SWAT simulations }\end{array}$ \\
\hline \multicolumn{2}{|c|}{$\begin{array}{l}\text { Animal feed production - } \\
\text { Forage Units/y }\end{array}$} & $\begin{array}{l}\text { Area mass balance - } \\
\text { Spreadsheet }\end{array}$ & $\begin{array}{l}\text { Examines and simulates animal feed consumption } \\
\text { and production. Consumption input data is from } \\
\text { regional statistics; production is from SWAT } \\
\text { simulations }\end{array}$ \\
\hline \multicolumn{2}{|c|}{$\begin{array}{l}\text { Energy production - } \\
\mathrm{kWh} / \mathrm{y}\end{array}$} & $\begin{array}{l}\text { Area mass balance - } \\
\text { Spreadsheet }\end{array}$ & $\begin{array}{l}\text { Estimates energy consumption and production at } \\
\text { landscape, data from regional statistics. }\end{array}$ \\
\hline \multicolumn{2}{|c|}{ Income generation $-€ / y$} & $\begin{array}{l}\text { Area balance - } \\
\text { Spreadsheet }\end{array}$ & $\begin{array}{l}\text { Estimates breakeven point of giant reed cultivation } \\
\text { for biofuel at farm level }\end{array}$ \\
\hline \multicolumn{2}{|c|}{$\begin{array}{l}\text { Employment generation - } \\
\text { FTE/y }\end{array}$} & $\begin{array}{l}\text { Area balance - } \\
\text { Spreadsheet }\end{array}$ & $\begin{array}{l}\text { Estimates direct FTE in agriculture combining data } \\
\text { of land use and local ratios of employment } \\
\text { generation (FTE/ha) for different crops }\end{array}$ \\
\hline \multicolumn{2}{|c|}{$\begin{array}{l}\text { GHG emissions - t CO2 } \\
\text { eq./y }\end{array}$} & $\begin{array}{l}\text { GHG emissions } \\
\text { inventory - Spreadsheet }\end{array}$ & $\begin{array}{l}\text { Examines and simulates GHG emissions from } \\
\text { animal farming and energy sector (electricity, heat } \\
\text { and transport) applying IPCC (2006) guidelines }\end{array}$ \\
\hline
\end{tabular}

\subsection{Interactive web interface}

We deployed the Ecometrica geospatial reporting tool [65] to develop an interactive platform where users and stakeholders could engage with this research. The results of our analyses were converted to maps (raster and vector maps) and subsequently uploaded on the platform where users could access the information (including summary statistics) from the maps. The interface allows 
users to view statistical summaries of the impacts of the alternative scenarios on the various indicators at spatial levels defined by the user [66].

\section{Results}

\subsection{Water availability}

The impacts of the biofuel project on water usage and availability was the most mentioned concern in our stakeholder assessment exercise (Table 1). The availability of irrigation water in the watershed reservoirs was simulated with the SWAT model for the baseline and the four biofuel scenarios. The simulation results, illustrated in Table 3, show that in all scenarios, with the exception of the Recycled Water scenario, the cultivation of giant reed initiated in the year 2011 requires water stored in the reservoirs.

Table 3. Model results of the effects of each biofuel scenario on the water stored in the reservoirs of the watershed. Values denote consumption of water stored as percentage of baseline values for the period May to October.

\begin{tabular}{|c|c|c|c|c|}
\hline Year & Company & Recycled Water & Polluted Land & Food \& Fuel \\
\hline 2009 & 0.00 & 0.00 & 0.00 & 0.00 \\
\hline 2010 & 0.00 & 0.00 & 0.00 & 0.00 \\
\hline 2011 & 2.20 & 0.00 & 2.05 & 1.85 \\
\hline 2012 & 2.33 & 0.00 & 2.17 & 1.95 \\
\hline 2013 & 2.30 & 0.00 & 2.14 & 1.93 \\
\hline 2014 & 2.43 & 0.00 & 2.27 & 2.04 \\
\hline 2015 & 2.25 & 0.00 & 2.10 & 1.89 \\
\hline 2016 & 3.55 & 0.00 & 3.31 & 2.97 \\
\hline 2017 & 4.19 & 0.00 & 3.90 & 3.51 \\
\hline 2018 & 2.08 & 0.00 & 1.93 & 1.74 \\
\hline
\end{tabular}

It is important to stress here that in all scenarios, except the Recycle Water, between 50 and 55\% of the giant reed is irrigated with water sourced outside the watershed. This is due to the proximity of these areas to reservoirs located outside the watershed (Figure 4). Another issue is that the results presented here are limited to the giant reed irrigation period, roughly May to October, corresponding to the summer months when overall demand for irrigation water is high and reservoir storage levels are low (Figure 4). In the Company scenario we observe the greatest 
impacts on the reservoirs of the watershed, while in the Recycle Water scenario there are no impacts since all irrigation water is provided by four wastewater treatment plants. 


\subsection{Biodiversity - habitat quality and connectivity}

In this study, habitat quality was used as a proxy measure of the status of biodiversity based on the assumption that areas of high quality maintain better biodiversity. Since the study did not focus on specific species, we considered 'full habitat' (100\% quality) all natural areas, including wetlands and forests, and 'semi-habitat' areas such as grasslands (50\% quality), tree plantations and perennial crops (30\% quality). The results of the InVEST model, displayed in Figure 5(a), show a value for the entire watershed of $12,184,916$ (no unit) representing the status of habitat quality in 2011.

Habitat connectivity was another proxy used to assess the status of biodiversity under the assumption that spatial location of habitat patches affects habitat quality. Figure 5(b) displays the habitat connectivity in the reference year. The results of Linkage Mapper show 4,443 habitat patches and 7,354 connections with an estimated level of fragmentation of 0.0276 (no unit) for the entire watershed.
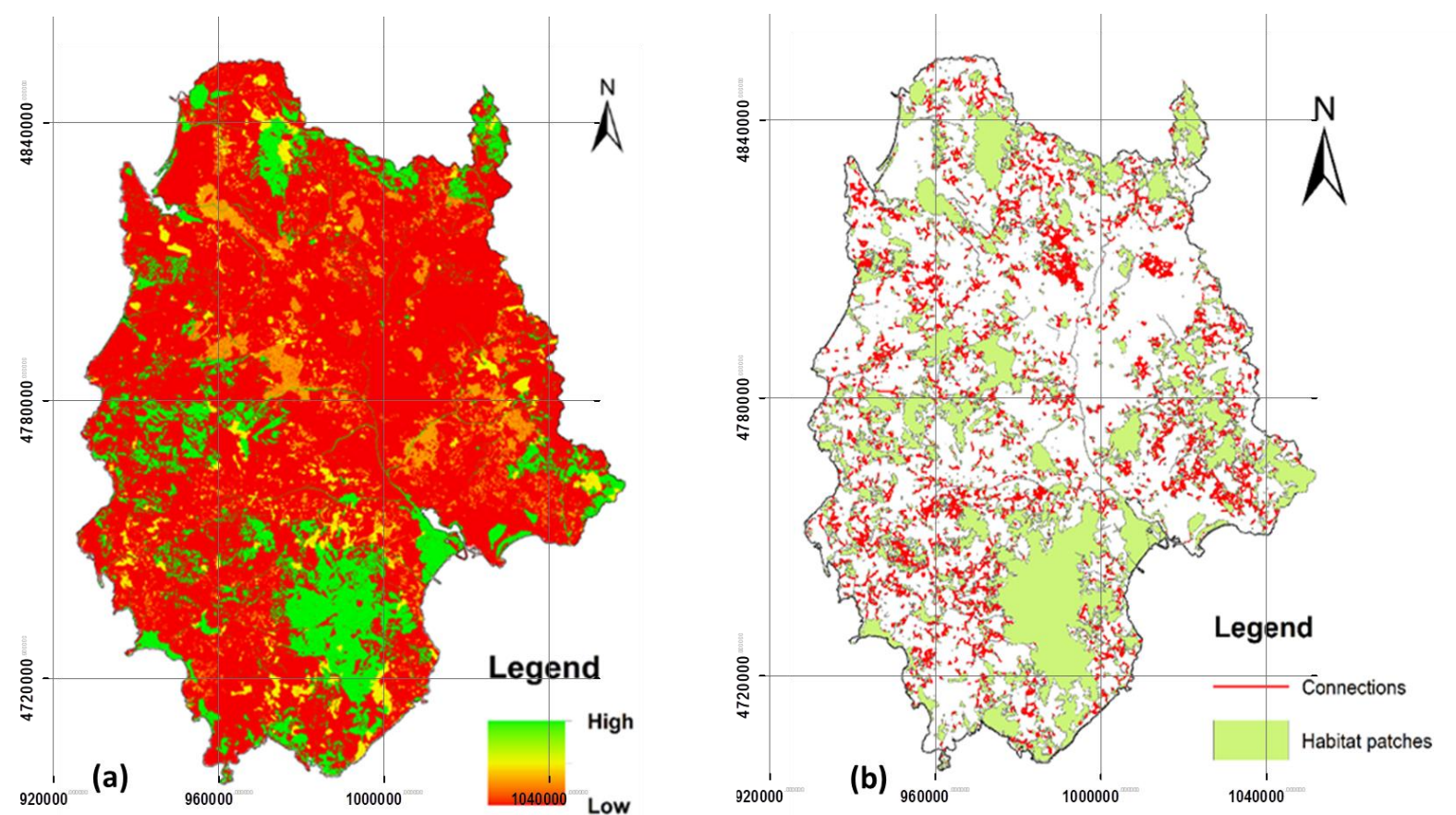

Figure 5. Baseline map of habitat quality (a) and spatial distribution of connections between patches of habitat in the study area (b) 
The results of the simulation of the biofuel scenarios showed an improvement of habitat quality in the reference year across all scenarios compared to the baseline (Table 4). The highest habitat quality was recorded under the Polluted Land scenario. There was also a generalised improvement of habitat connectivity with the highest value recorded under the Food scenario.

Table 4. Model results of habitat quality and connectivity in the watershed area

\begin{tabular}{|r|l|l|l|l|l|l|}
\hline Indicators & Unit & Baseline & Company & $\begin{array}{l}\text { Recycled } \\
\text { Water }\end{array}$ & $\begin{array}{l}\text { Polluted } \\
\text { Land }\end{array}$ & Food \& Fuel \\
\hline Habitat Size & $\mathrm{Ha}$ & +0.04 & +0.03 & +0.03 & +0.02 & +0.04 \\
\hline Habitat Quality & Unitless & $12,184,916$ & $+2.5 \%$ & $+4.1 \%$ & $+4.5 \%$ & $+1.2 \%$ \\
\hline $\begin{array}{r}\text { Habitat } \\
\text { Connectivity }\end{array}$ & $\begin{array}{l}\text { Number } \\
\text { connections }\end{array}$ & 7,354 & $+20.9 \%$ & $+0.7 \%$ & $+1.2 \%$ & $+56 \%$ \\
\hline Habitat patches & Count & 4,443 & 6,231 & 4,511 & 4,497 & 5,759 \\
\hline Fragmentation & Unitless & 0.0276 & $+35 \%$ & $-2 \%$ & $-1.2 \%$ & $+27.2 \%$ \\
\hline
\end{tabular}

Notes: scenario percentage values are calculated against baseline values

\subsection{Climate regulation - emissions of GHG}

A critical motivation behind the use of biofuel for transport is the reduction of GHG emissions compared to fossil fuel use. Area based GHG emissions were modelled based on consumption of heat, electricity and transport fuels as well as emissions of animal farming activities (Figure 6). Emissions related to electricity exports are not accounted for, while emissions due to grid losses are included. The spatial distribution of GHG emissions in the watershed (Figure 6) shows a concentration in the regional capital, Cagliari, due to transport fuels and electricity consumption, as well as in specific areas where large quantities of heat are used by the chemical industry.

The results of the scenario analysis show that the reduction of GHG emissions due to the biofuel project is concentrated in the transport and electricity sectors with no differences between the four biofuel scenarios. In the transport sector, 80,000tons of ethanol per year are used to substitute gasoline with savings of c.125,850tons of $\mathrm{CO} 2$ eq. In the electricity sector, the biofuel project provides c.448,000tons of lignin a year which can be used as feedstock for co-firing with coal at a near-by power plant. In this way, the project contributes to reduce the GHG emissions of the power 
plant by c.133,100tons CO2 eq. per year. Overall, these savings correspond to an estimated reduction of $3 \%$ of total climate changing emissions in the watershed ${ }^{1}$.

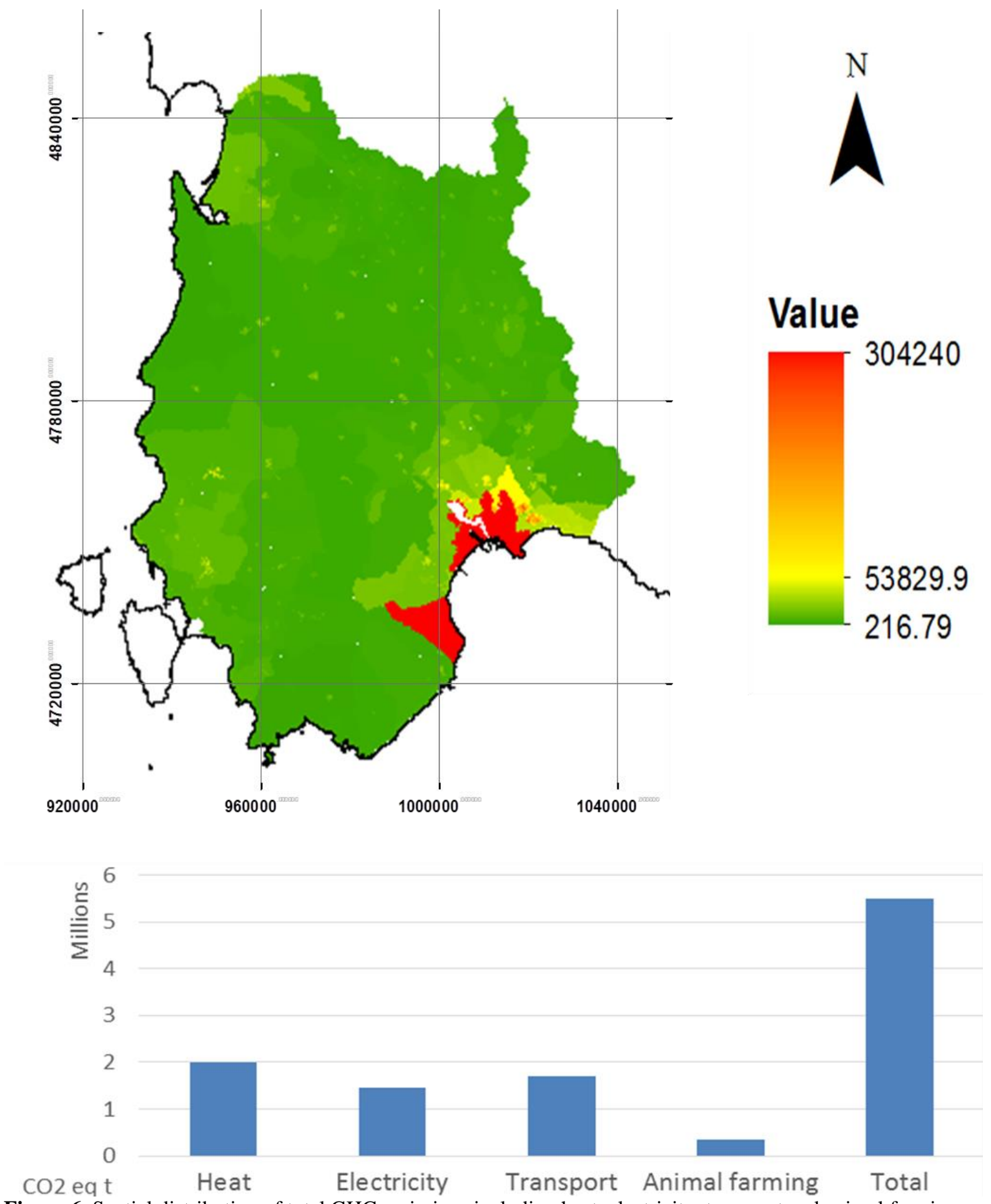

Figure 6. Spatial distribution of total GHG emissions including heat, electricity, transport and animal farming Notes: Unit is ton $\mathrm{CO}_{2}$ eq./ha. Chart showing model results of GHG emissions in the watershed for the reference year (2011).

\footnotetext{
${ }^{1}$ No impacts on the emissions of the heat and animal farming sectors.
} 
Figure 7. Consumption and production of energy, food and animal feed in the watershed Notes: reference year 2011; displayed units are: Million Kcal (food), 100 MWh (energy), and 1000 Forage Unit

\section{(animal feed). used for animal farming.}

4.4 Provision of energy, food and animal feed

We modelled the production of energy, food and animal feed in the watershed and compared that against consumption levels of the year 2011. The results presented in Figure 7 show a mixed picture. The area appears largely self-sufficient for what concerns energy, with a large oversupply of transport fuels. At the same time, it is reliant on imports of food and animal feed. In particular, in 2011 the area was a net exporter of both transport fuels (produced in large volumes from imported crude oil), and electricity; while it is essentially in balance for heat. Regarding food, the results show that the area is dependent on imports of processed and unprocessed food as crops and meat, while it has an overproduction of dairy products with sheep milk production being a key activity in the area. Finally, the area is dependent on imports for cereal grains, forage and straw

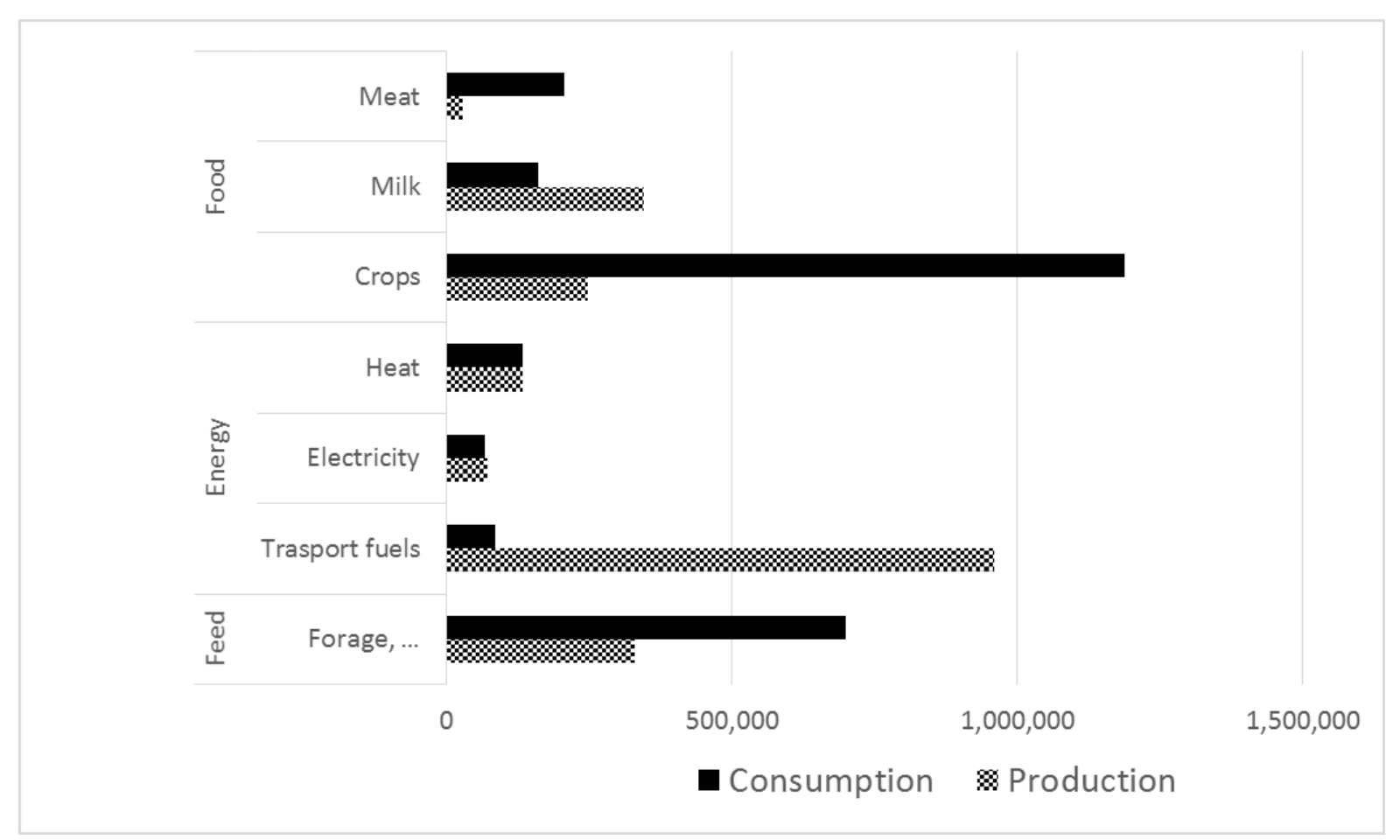

The state of the area in the baseline was then compared against the simulated state under each of the four biofuel scenarios (Table 5). Overall, all biofuel scenarios show an increased supply 
(production) of energy in the form of transport fuels and electricity, and a very limited increase in energy consumption $(0.16 \mathrm{GWh}$ - corresponding to $0.0005 \%$ of total energy consumption in the study area) due to the production of biofuel (from giant reed to ethanol). This slightly increases the amount of energy available for export ranging around $75 \%$ of total energy production. However, the biofuel project contributes to an increased use of local resources in energy generation from $9 \%$ to $12 \%$ compared to the Baseline. Regarding the food sector, the analysis found that while the biofuel project does not affect local consumption, it reduces local production and, thus, increases net imports in all scenarios except in the Food and Fuel scenario. In this case, food production is higher due to an increase of durum wheat acreage of c. $150 \%$. Finally, the biofuel project hinders production of animal feed in the area with a reduction of between c. 4.3 and $8.5 \%$ across the scenarios. The conversion to giant reed of graze land as well as abandoned and fallow agricultural land reduces the land available for sheep farming, thus, increasing reliance on feed imports to the area. The lowest reduction is observed under the Food \& Fuel scenario since the giant reed acreage in that scenario is c. $25 \%$ lower than in the other scenarios.

Table 5. Effects of the biofuel project on the provision of energy, food and animal feed in the watershed

\begin{tabular}{|l|l|l|l|l|l|l|l|}
\hline \multicolumn{2}{|l}{ Indicator } & Unit & Baseline & Company & $\begin{array}{l}\text { Recycled } \\
\text { Water }\end{array}$ & $\begin{array}{l}\text { Polluted } \\
\text { Land }\end{array}$ & $\begin{array}{l}\text { Food \& } \\
\text { Fuel }\end{array}$ \\
\hline \multirow{2}{*}{ Food } & $\mathrm{P}$ & M Kcal & 620,893 & $0 \%$ & $-27 \%$ & $0 \%$ & $+36 \%$ \\
\cline { 2 - 8 } & $\mathrm{C}$ & M Kcal & $1,553,000$ & $0 \%$ & $0 \%$ & $0 \%$ & $0 \%$ \\
\hline \multirow{2}{*}{$\begin{array}{l}\text { Animal } \\
\text { feed }\end{array}$} & $\mathrm{P}$ & $\mathrm{UF}$ & 328.421 & $-7.3 \%$ & $-4.9 \%$ & $-4.3 \%$ & $-8.5 \%$ \\
\cline { 2 - 8 } & $\mathrm{C}$ & UF & 698,508 & $0 \%$ & $0 \%$ & $0 \%$ & $0 \%$ \\
\hline \multirow{2}{*}{ Energy } & $\mathrm{P}$ & GWh & 116,226 & $0.6 \%$ & $0.6 \%$ & $0.6 \%$ & $0.6 \%$ \\
\cline { 2 - 8 } & $\mathrm{C}$ & GWh & 28,414 & $0 \%$ & $0 \%$ & $0 \%$ & $0 \%$ \\
\hline
\end{tabular}

Notes: percentages are calculated against baseline values; 'P' stands for production, 'C' for consumption; UF represents forage units> 


\subsection{Generation of employment and income}

Local stakeholders engaged in this study considered the generation of employment and income as clear opportunities of the biofuel project due to the high unemployment and lack of economic activities in the area. Regarding employment, we first quantified the demand of labour created by the industrial, transport and agricultural activities of the biofuel project in each biofuel scenario. The analysis showed that the project is expected to employ 80 workers for industrial activities in all the scenarios and between 7 and 12 for transport activities. Transport contribution depends on the distance between the plant and the giant reed estates, which varies across the scenarios. However, the quantification of employment in agriculture is much more uncertain. Our analysis applied an average of 25 work hours per hectare of giant reed per year (interviews). Based on these values, the project generates between 204 FTE positions (Food and Fuel scenario) and 274 FTE (Recycled water scenario). When we compare these values against total employment in agriculture in the study area, estimated at 27,923 FTE, the contribution of the project appears marginal at best. However, it is important to note here that the total area converted to giant reed for the project is c. $1.5 \%$ of the total agricultural land in the watershed.

Regarding income generation, we limited the analysis to the effects within farms cultivating the biofuel feedstock. We estimated returns at farm level based on a reference price of $70 € /$ ton DM for giant reed, which is slightly higher than the calculated minimum price that makes the farm activity viable and much higher than the price the biofuel project was expecting to pay for the feedstock ( $40 € /$ ton DM based on interviews). The difference between the two price levels is evidence that the biofuel investor largely underestimated the farm level costs involved in the cultivation of giant reed.

The results show a relatively high breakeven point at 31.6 ton DM per ha. At 35 ton/ha, at the higher end of the results of the field trials [38], the cultivation of giant reed results in net income of $237 € /$ ha per year (accounting for production costs including planting and harvesting, fertilisers, 
land rent, irrigation infrastructure and labour $)^{2}$. In the analysis of the Food \& Fuel scenario, we considered the use of cereal straw as biofuel feedstock with straw prices in the range of $40 € /$ ton (interviews) and grain prices of durum wheat of $220 € /$ ton. The results show that expanding the cultivation of durum wheat for biofuel production generates an important net loss of c. 1199€/ha. Based on the number of hectares converted in each scenario, we modelled the contribution of the biofuel project to income generation in the entire watershed. Table 6 presents the results as changes of income in each scenario against the baseline values, i.e. previous land use. Overall, the effects of the project are positive in all scenarios except the Food and Fuel scenario, due to the large unprofitability (without considering government subsidies) of cultivating durum wheat in the area.

Table 6. Area based effects on employment and income

\begin{tabular}{|c|c|c|c|c|c|}
\hline Indicators & Description & Company & $\begin{array}{l}\text { Recycled } \\
\text { Water }\end{array}$ & $\begin{array}{l}\text { Polluted } \\
\text { Land }\end{array}$ & Food \& Fuel \\
\hline \multirow{2}{*}{$\begin{array}{l}\text { Land use } \\
\text { change (ha) }\end{array}$} & Giant reed & 6,000 & 6000 & 6000 & 4500 \\
\hline & Wheat & 0 & 0 & 0 & 27200 \\
\hline Income $(€)$ & $\begin{array}{l}\text { Difference to } \\
\text { baseline }\end{array}$ & 908,000 & $2,185,000$ & $1,800,000$ & - 35,298,000 \\
\hline \multirow{2}{*}{$\begin{array}{l}\text { Employment } \\
\text { (FTE) }\end{array}$} & $\begin{array}{l}\text { Industrial \& } \\
\text { transport }\end{array}$ & 92 & 89 & 87 & 89 \\
\hline & Agriculture & 272 & 274 & 272 & 204 \\
\hline
\end{tabular}

\section{Discussion}

This research revealed interesting outcomes that could arise from the implementation and operation of a biofuel refinery in Sardinia, Italy. Results from several possible scenarios under which large-scale production of biofuel could be implemented, identified potential impacts on key environmental and socioeconomic indicators such as biodiversity and habitat quality, food and animal feed availability, GHG emissions, energy availability, employment and income generation. This research found that in many ways the establishment of a large-scale biorefinery in the landscape positively affects the livelihood and ecosystems of the area. A summary of the results

\footnotetext{
2 The costs of water for irrigation as well as the collection and transport of the giant reed to the biofuel plant are borne by the biofuel project (Interviews with project representatives).
} 
Table 7. Changes of indicators in scenarios as percentage of baseline values

\begin{tabular}{|c|c|c|c|c|c|}
\hline \multirow{2}{*}{ Category } & \multirow{2}{*}{ Indicator } & \multicolumn{4}{|c|}{ Scenarios } \\
\hline & & Company & Recycled Water & $\begin{array}{l}\text { Polluted } \\
\text { Land }\end{array}$ & $\begin{array}{c}\text { Food and } \\
\text { Fuel }\end{array}$ \\
\hline Water & $\begin{array}{l}\text { Water stored in } \\
\text { reservoirs }^{\mathrm{a}}\end{array}$ & $K-2.67$ & オ 0 & $\measuredangle-2.48$ & $K-2.23$ \\
\hline \multirow{3}{*}{ Biodiversity } & Habitat quality & ス 2.5 & フ 4.1 & オ 4.5 & オ 1.2 \\
\hline & Habitat connectivity ${ }^{\mathrm{b}}$ & ス 20.9 & ス 0.7 & オ 1.2 & ス 56.2 \\
\hline & Habitat fragmentation & $\measuredangle 35.0$ & ス -2.0 & $\nearrow-1.2$ & $\measuredangle 27.2$ \\
\hline Climate & Total GHG emissions & $\lambda-3.0$ & $\lambda-3.0$ & ス -3.0 & $\lambda-3.0$ \\
\hline \multirow{3}{*}{ Production of ${ }^{\mathrm{c}}$} & Food & $K-0.4$ & $K-0.8$ & $K-0.6$ & ス 36.0 \\
\hline & Animal feed & $\measuredangle-7.3$ & $\swarrow-4.9$ & $\nvdash-4.3$ & $<-8.5$ \\
\hline & Energy & オ 0.6 & オ 0.6 & ス 0.6 & ス 0.6 \\
\hline Employment & Agricultural sector & オ 0.8 & オ 1.7 & ス 1.6 & オ 3.4 \\
\hline Income $^{\mathrm{d}}$ & Profitability & $\lambda$ YES & $\lambda$ YES & $\lambda$ YES & $\angle N O$ \\
\hline
\end{tabular}

Notes: Arrows direction indicates the quality of change ( $\nearrow$ positive and $\measuredangle$ negative)

${ }^{a}$ Change of water stored in reservoirs with reference to the giant reed irrigation period

${ }^{\mathrm{b}}$ Change of number of connections between habitat patches

${ }^{\mathrm{c}}$ Reference only to production because consumption of food and feed is not expected to change under a biofuel scenario, while energy consumption increases only marginally.

${ }^{\mathrm{d}}$ As total net income of giant reed against that of previous land use for all areas affected by LUC

Findings from this research indicate that the biofuel refinery project generally improves biodiversity and ecosystem services in the landscape. Table 7 shows improvements in habitat quality and connectivity, despite an observed increase in habitat fragmentation in the Company and Food \& Fuel scenarios. The greatest improvement in habitat quality was recorded under the Polluted Land, followed by the Recycled Water scenario. This is valid considering that the Polluted 
Land scenario has at its core the production of giant reed on land officially classified as contaminated.

Moreover, the project is expected to lead to GHG emission savings across all scenarios (Table 7). This is a potentially good outcome since the reduction of GHG emissions is one of the drivers of the promotion of biofuel production. However, critical trade-offs emerge with respect to food and animal feed production across all the scenarios with the exception of the Food \& Fuel scenario. Food production is lowest under the Recycled Water scenario, followed by the Polluted Land, while animal feed production is lowest under the Food \& Fuel, followed by the Company scenario. In the Food \& Fuel scenario negative impacts on food production are mitigated by increasing the acreage of durum wheat in the catchment area. However, this reduces the quantity of animal feed produced since pastureland is converted to wheat production.

The modelling results show a general improvement of employment levels and income generation (Table 7). Local stakeholders engaged in this study considered these as critical opportunities due to the high unemployment and lack of economic activities in the area. An exception is the Food \& Fuel scenario in which the generation of employment in agriculture is marginally lower compared to the baseline because giant reed, which has a higher demand of labour per hectare cultivated, has a smaller share in that scenario. Furthermore, with respect to income, the cultivation of durum wheat for biofuel production (under the Food \& Fuel) generates a net loss for farmers of c. 1199 $€ /$ ha.

Although no one scenario satisfied all the concerns raised by the stakeholders, some of the scenarios are more beneficial than the proposed Company scenario. Similarly, the combination of different scenarios could provide additional benefits. For instance, the combination of the Food \& Fuel with the Recycled Water scenario could lead to reduced impact on water availability and, at the same time, improvement in, e.g. biodiversity and food production. 
The findings from this research buttress the importance of understanding the trade-offs encountered in the implementation of such large-scale project, as early as possible. The various modelling undertaken demonstrated how various aspects of the ecosystem, livelihood and other socioeconomic activities of an area of interest could be affected (positively and negatively) with changes in the landscape. Hence, the undertaking of studies such as this should form a critical part of the planning and implementation of biofuel projects. Relevant stakeholders in such areas should be carried along during the planning and implementation phases to improve communication, address unfounded perceptions, and foster collaboration in identifying operational conditions that are acceptable by all relevant parties. The identification of barriers and opportunities at an early stage of project development can benefit investors as well as local communities. The involvement of local stakeholders in the modelling of effects on ecosystem services, which is a key component of the approach developed for this analysis, provides the local community with the knowledge needed to contribute to the design, implementation and monitoring of projects, increasing the acceptability and support for such high-stake investments.

The deployment of geospatial technology to implement the landscape design modelling undertaken in this project contributed to simplify the complexities often encountered in understanding changes in landscape dynamics. It enabled the modelling and understanding of current and future distribution of ecosystem and societal services, potential winners and losers, as well as the perceived needs and expectations of stakeholders in relation to these services. In our approach to landscape design, we apply an integrative and participatory modelling approach to provide the interdisciplinary knowledge needed to address all issues considered important by stakeholders. However, our application of a Couple Component Modelling [65] is affected by the need to manually link models' outputs, the limited ability to account for uncertainties and feedback effects, e.g. changes of livestock population due to changes of animal feed prices, as well as by limitations in terms of time and other resources required to develop and run the models. 


\section{Conclusion}

The main contribution of this research is the deployment of geospatial techniques alongside other analytical and modelling tools to develop an integrated landscape approach for the design of largescale biofuel projects. The approach was tested on the case study of advanced cellulosic ethanol from giant reed in Sardinia (Italy). The approach adopted a systems perspective to account for spatial heterogeneity and the influence of contextual conditions. It relied on collaborative research with the engagement of local stakeholders and experts. Geospatial techniques were adopted to understand how the introduction of a biorefinery could drive changes in land use, environment, social issues and the economy of an area. These provided a robust and practical way to develop the knowledge required for landscape design due to their ability to integrate, manage and analyse information from a wide range of sources.

Key indicators identified with the active participation of local stakeholders were used to assess the various impacts of the project, under different alternative landscape scenarios for project implementation. The analysis revealed an overall positive effect of the project in the watershed. This is a significant outcome as the general perception in public debates, but also among local communities, tends to focus on potentially negative outcomes occasioned by changes in land use and land cover. In our case study, potential trade-offs emerged in the food and animal feed sectors. However, these can be mitigated by supporting food production in the area as simulated in the Food \& Fuel scenario. For this, project developers and local policy makers could introduce measures to improve the productivity of wheat cultivation, which has been largely unprofitable in the study area in recent years.

The knowledge developed in the case study was used to facilitate consensus building among local stakeholders. We observed a significant change in the attitudes and views of those involved in the last workshop compared to those expressed by the same individuals in the initial interviews. Engagement throughout the research process provided a common understanding and the basis for 
building a level of agreement about the project and its effects. In view of negative perception and various local oppositions to biofuel production, this research confirms that successful implementation of biofuel projects could be facilitated if pre-emptive landscape design processes were employed to identify and address concerns before they became a problem. It is expected that the integrated approaches $[65,67,68]$ adopted in this research could be deployed in investigating the environmental, social, political and economic interactions associated with the commissioning of large projects in communities.

\section{Acknowledgement}

This research was funded by Shell Global Solutions International. We thank colleagues at the Regional Agricultural Agency of Sardinia for their valuable contributions to this research.

\section{References}

[1] L. Wang, J. Littlewood, R.J. Murphy, Environmental sustainability of bioethanol production from wheat straw in the UK, Renew. Sustain. Energy Rev. 28 (2013) 715-725. https://doi.org/10.1016/j.rser.2013.08.031.

[2] A. Sharman, J. Holmes, Evidence-based policy or policy-based evidence gathering? Biofuels, the EU and the 10\% target, Environ. Policy Gov. 20 (2010) 309-321. https://doi.org/10.1002/eet.543.

[3] M. Balat, An overview of biofuels and policies in the European union, Energy Sources, Part B Econ. Plan. Policy. 2 (2007) 167-181. https://doi.org/10.1080/15567240500402701.

[4] A. Haj Hasan, A. Avami, Comparative assessment of bioethanol supply chain: insights from Iran, Biofuels. (2018). https://doi.org/10.1080/17597269.2018.1496385.

[5] R.A. Holland, F. Eigenbrod, A. Muggeridge, G. Brown, D. Clarke, G. Taylor, A synthesis of the ecosystem services impact of second generation bioenergy crop production, Renew. Sustain. Energy Rev. 46 (2015) 30-40. https://doi.org/10.1016/j.rser.2015.02.003.

[6] R. Sims, M. Taylor, J. Saddler, W. Mabee, From 1st - to 2nd- Generation Biofuel 
Technologies, IEA Bioenergy. 21 (2008) 5-6.

[7] I.R.E.A. (IRENA), Innovation Outlook: Advanced Liquid Biofuels, /Publications/2016/Oct/Innovation-Outlook-Advanced-Liquid-Biofuels. (n.d.).

[8] Helena Tavares Kennedy, Andeavor to convert Dickinson Refinery to renewable diesel : $\begin{array}{llll}\text { Biofuels } & \text { Digest, } & 2018 . & \text { (n.d.). }\end{array}$ https://www.biofuelsdigest.com/bdigest/2018/08/11/andeavor-to-convert-dickinsonrefinery-to-biodiesel/ (accessed October 20, 2019).

[9] Y. Chen, S. Ale, N. Rajan, C. Munster, Assessing the hydrologic and water quality impacts of biofuel-induced changes in land use and management, GCB Bioenergy. 9 (2017) 14611475. https://doi.org/10.1111/gcbb.12434.

[10] A. Demirbas, Political, economic and environmental impacts of biofuels: A review, (2009). https://doi.org/10.1016/j.apenergy.2009.04.036.

[11] S. Milner, R.A. Holland, A. Lovett, G. Sunnenberg, A. Hastings, P. Smith, S. Wang, G. Taylor, Potential impacts on ecosystem services of land use transitions to second-generation bioenergy crops in GB, GCB Bioenergy. $8 \quad$ (2016) 317-333. https://doi.org/10.1111/gcbb.12263.

[12] H. de Gorter, D.R. Just, The social costs and benefits of biofuels: The intersection of environmental, energy and agricultural policy, Appl. Econ. Perspect. Policy. 32 (2010) 432. https://doi.org/10.1093/aepp/ppp010.

[13] G. Moschini, J. Cui, H. Lapan, Economics of Biofuels: An Overview of Policies, Impacts and Prospects, (n.d.). www.fupress.com/bae (accessed October 20, 2019).

[14] A. Mohr, S. Raman, Lessons from first generation biofuels and implications for the sustainability appraisal of second generation biofuels, Effic. Sustain. Biofuel Prod. Environ. Land-Use Res. (2015) 281-310. https://doi.org/10.1016/j.enpol.2013.08.033.

[15] N.Y. Amponsah, M. Troldborg, B. Kington, I. Aalders, R.L. Hough, Greenhouse gas 
emissions from renewable energy sources: A review of lifecycle considerations, Renew. Sustain. Energy Rev. 39 (2014) 461-475. https://doi.org/10.1016/j.rser.2014.07.087.

[16] D. Tilman, J. Hill, C. Lehman, Carbon-negative biofuels from low-input high-diversity grassland biomass, Science (80-. $\quad$ ). $314 \quad$ (2006) 1598-1600. https://doi.org/10.1126/science.1133306.

[17] UNCTAD, unctad.org | Second-Generation Biofuel Markets: State of Play, Trade and Developing Country Perspectives, (2016) https://unctad.org/en/pages/PublicationWebflyer.aspx?publicationid=1455 （accessed October 20, 2019).

[18] I. Sachs, United Nations Conference on Trade and Development The Biofuels Controversy, Revue. (2007) 28. www.UNCTAD.org.

[19] International Energy Agency, Sustainable Production of SECOND -Generation Biofuels: Potential and perspectives in major economies and developing countries, 2010.

[20] S.N. Naik, V. V. Goud, P.K. Rout, A.K. Dalai, Production of first and second generation biofuels: A comprehensive review, Renew. Sustain. Energy Rev. 14 (2010) 578-597. https://doi.org/10.1016/j.rser.2009.10.003.

[21] J.L. Ramos, M. Valdivia, F. García-Lorente, A. Segura, Benefits and perspectives on the use of biofuels, Microb. Biotechnol. 9 (2016) 436-440. https://doi.org/10.1111/17517915.12356.

[22] Energy Technologies Institute, The evidence for deploying Bioenergy with CCS (BECCS) in the UK, 2016. https://d2umxnkyjne36n.cloudfront.net/insightReports/The-Evidence-forDeploying-Bioenergy-with-CCS-in-the-UK.pdf?mtime=20161107110603 (accessed October 20, 2019).

[23] A.C.R. Teixeira, J.R. Sodré, L.L.N. Guarieiro, E.D. Vieira, F.F. De Medeiros, C.T. Alves, A Review on Second and Third Generation Bioethanol Production, in: SAE Tech. Pap., 
SAE International, 2016. https://doi.org/10.4271/2016-36-0515.

[24] M. Valdivia, J.L. Galan, J. Laffarga, J.-L. Ramos, Biofuels 2020: Biorefineries based on lignocellulosic materials, Microb. Biotechnol. $9 \quad$ (2016) 585-594. https://doi.org/10.1111/1751-7915.12387.

[25] K. Araújo, D. Mahajan, R. Kerr, M. Da Silva, Global biofuels at the crossroads: An overview of technical, policy, and investment complexities in the sustainability of biofuel development, Agric. 7 (2017). https://doi.org/10.3390/agriculture7040032.

[26] Maria Wellisch, Sustainability Planning and Assessment - Essential Part of Biorefinery Design, in: 2010.

[27] V.H. Dale, K.L. Kline, M.A. Buford, T.A. Volk, C. Tattersall Smith, I. Stupak, Incorporating bioenergy into sustainable landscape designs, Renew. Sustain. Energy Rev. 56 (2016) 1158-1171. https://doi.org/10.1016/j.rser.2015.12.038.

[28] M. Dosskey, G. Wells, G. Bentrup, D. Wallace, Enhancing ecosystem services: Designing $\begin{array}{lllllll}\text { for multifunctionality, } & \text { J. SOIL WATER } & \text { Conserv. } 67 & \text { (2012). }\end{array}$ https://doi.org/10.2489/jswc.67.2.37A.

[29] R.S. de Groot, R. Alkemade, L. Braat, L. Hein, L. Willemen, Challenges in integrating the concept of ecosystem services and values in landscape planning, management and decision making, Ecol. Complex. 7 (2010) 260-272. https://doi.org/10.1016/j.ecocom.2009.10.006.

[30] B. Lattimore, C.T. Smith, B.D. Titus, I. Stupak, G. Egnell, Environmental factors in woodfuel production: Opportunities, risks, and criteria and indicators for sustainable practices, Biomass and Bioenergy. 33 (2009) 1321-1342. https://doi.org/10.1016/j.biombioe.2009.06.005.

[31] M. Debolini, E. Marraccini, D. Rizzo, M. Galli, E. Bonari, Mapping local spatial knowledge in the assessment of agricultural systems: A case study on the provision of agricultural services, Appl. Geogr. 42 (2013) 23-33. https://doi.org/10.1016/j.apgeog.2013.04.006. 
[32] S. Nijhuis, Applications of GIS in landscape design research, Res. Urban. Ser. 4 (2016) $43-$ 56. https://doi.org/10.7480/rius.4.1367.

[33] Biochemtex, A new era begins: Crescentino World's first advanced biofuels facility., in: Off. Open. Cerem. World's 1st Commer. Cellul. Ethanol Plant Crescentino Bio- refinery. Wednesday, Oct. 9th 2013, 2013.

[34] Jim Lane, Italy mulling prospects for 79 million gallons of advanced biofuels capacity: Biofuels Digest, (2014). http://www.biofuelsdigest.com/bdigest/2014/05/27/italy-mullingprop-sects-for-adding-79-million-gallons-of-advanced-biofuels-capacity/_accessed October 20, 2019).

[35] J. Lane, What are- and who's making- 2G, 3G, and 4G biofuels?, Biofuels Dig. (2010) 1. http://bioenergyuiuc.blogspot.com/2010/05/what-are-and-whos-making-2g-3g-and4g.html.

[36] Grati, Personal communication, (2015).

[37] G. Pulighe, G. Bonati, S. Fabiani, T. Barsali, F. Lupia, S. Vanino, P. Nino, P. Arca, P.P. Roggero, Assessment of the Agronomic Feasibility of Bioenergy Crop Cultivation on Marginal and Polluted Land: A GIS-Based Suitability Study from the Sulcis Area, Italy, Energies. 9 (2016) 1-18. https://doi.org/10.3390/en9110895.

[38] P. Arca, Cropping systems for biomass production under Mediterranean conditions: implantation techniques and soil carbon balance - CORE, 2017. https://core.ac.uk/display/96178791 (accessed October 21, 2019).

[39] NASA, EarthData, (2020).

[40] Copernicus Programme, CLC 2012, (2020).

[41] R.A. for A. and R. Development, Agricultural land database, 2008.

[42] S. regional Government, Sardinia geoportal, 2017. http://www.sardegnageoportale.it/.

[43] Italian National Institute of Statistics (ISTAT), Crops statistics - areas and production, 
2018.

[44] and R.J.H. Fick, S.E., WorldClim 2: new $1 \mathrm{~km}$ spatial resolution climate surfaces for global land areas., Int. J. Climatol. . 37 (2017) 4302-4315.

[45] National Institute of Agricultural Economics. (INEA), Atlante dell'Irrigazione Regioni Meridionali; Rapporti Irrigazione, Rome, Italy, 2001.

[46] M. Winchell, R. Srinivasan, M. Di Luzio, J. Arnold, SWAT Help, Texas Agrilife Res. United States Dep. Agric. Agric. Research Serv. (2013).

[47] G.F. Ricci, A.M. De Girolamo, O.M.M. Abdelwahab, F. Gentile, Identifying sediment source areas in a Mediterranean watershed using the SWAT model, L. Degrad. Dev. 29 (2018) 1233-1248. https://doi.org/10.1002/ldr.2889.

[48] O.M.M. Abdelwahab, G.F. Ricci, A.M. De Girolamo, F. Gentile, Modelling soil erosion in a Mediterranean watershed: Comparison between SWAT and AnnAGNPS models, Environ. Res. 166 (2018) 363-376. https://doi.org/10.1016/j.envres.2018.06.029.

[49] F. Hallouz, M. Meddi, G. Mahé, S. Alirahmani, A. Keddar, Modeling of discharge and sediment transport through the SWAT model in the basin of Harraza (Northwest of Algeria), Water Sci. 32 (2018) 79-88. https://doi.org/10.1016/j.wsj.2017.12.004.

[50] D. Waidler, M. White, E. Steglich, S. Wang, J. Williams, C.A. Jones, R. Srinivasan, Conservation Practice Modeling Guide for SWAT and APEX, J. Hydrol. 50 (2011) 30-49. https://doi.org/10.1017/CBO9781107415324.004.

[51] N.J. Rosenberg, D.J. Epstein, D. Wang, L. Vail, R. Srinivasan, J.G. Arnold, Possible impacts of global warming on the hydrology of the Ogallala aquifer region, Clim. Change. 42 (1999) 677-692. https://doi.org/10.1023/A:1005424003553.

[52] P. W. Gassman, M. R. Reyes, C. H. Green, J. G. Arnold, The Soil and Water Assessment Tool: Historical Development, Applications, and Future Research Directions, Trans. ASABE. 50 (2007) 1211-1250. https://doi.org/10.13031/2013.23637. 
[53] J. Sharp, R., Tallis, H.T., Ricketts, T., Guerry, A.D., Wood, S.A., Chaplin-Kramer, R., Nelson, E., Ennaanay, D., Wolny, S., Olwero, N., Vigerstol, K., Pennington, D., Mendoza, G., Aukema, J., Foster, J., Forrest, J., Cameron, D., Arkema, K., Lonsdorf, E., K, InVEST +VERSION+ User's Guide., 2016.

[54] S.M. Nelson E, Bhagabati N, Ennaanay D, Lonsdorf E, Pennington D, Modeling terrestrial ecosystem services., in: E. Levin S (Ed.), Encycl. Biodiversity., 2nd Volume, Waltham, MA: Academic Press, 2013: pp. 347-61.

[55] G.T. Duarte, M.C. Ribeiro, A.P. Paglia, Ecosystem Services Modeling as a Tool for Defining Priority Areas for Conservation, PLoS One. 11 (2016) e0154573. https://doi.org/10.1371/journal.pone.0154573.

[56] Circuitscape., Linkage Mapper., (2017).

[57] and B.H.M. Shah, Viral B., Circuitscape: a tool for landscape ecology., in: Proc. 7th Python Sci. Conf. Calif. SciPy Conf., 2008: p. Vol. 7.

[58] L. Di Lucia, B. Ribeiro, Enacting responsibilities in landscape design: The case of advanced biofuels, Sustain. 10 (2018). https://doi.org/10.3390/su10114016.

[59] Region Sardinia, Piano regionale di bonifica delle aree inquinate, Cagliari, 2018. https://portal.sardegnasira.it/-/aggiornamento-del-piano-regionale-bonifica-siti-inquinati-.

[60] D.J. Immerzeel, P.A. Verweij, F. van der Hilst, A.P.C. Faaij, Biodiversity impacts of bioenergy crop production: A state-of-the-art review, GCB Bioenergy. 6 (2014) 183-209. https://doi.org/10.1111/gcbb.12067.

[61] GOVIT, National database of livestock, 2018.

[62] Cannas, Personal communication, (2016).

[63] IPCC - The Intergovernmental Panel on Climate Change, 2006 IPCC Guidelines for National Greenhouse Gas Inventories. https://www.ipcc-nggip.iges.or.jp/public/2006gl/, (2006). 
[64] Regione Sardegna, Regione Autonoma Della Sardegna-Sardegna Geoportale., (2015).

[65] R.A. Kelly, A.J. Jakeman, O. Barreteau, M.E. Borsuk, S. ElSawah, S.H. Hamilton, H.J. Henriksen, S. Kuikka, H.R. Maier, A.E. Rizzoli, H. van Delden, A.A. Voinov, Selecting among five common modelling approaches for integrated environmental assessment and management, Environ. Model. Softw. $47 \quad$ (2013) 159-181. https://doi.org/10.1016/j.envsoft.2013.05.005.

[66] C. for E.P.I.C. London, Sardinia Integrated Land Management Solutions for Sustainable Bioeconomy (ILAMS), (2016). $\quad$ https://sardiniailams.imperialac.ourecosystem.com/interface/.

[67] B.A. Van Asselt Marjolein, N. Rijkens-Klomp, A look in the mirror: Reflection on participation in Integrated Assessment from a methodological perspective, Glob. Environ. Chang. 12 (2002) 167-184. https://doi.org/10.1016/S0959-3780(02)00012-2.

[68] A. Voinov, F. Bousquet, Modelling with stakeholders, Environ. Model. Softw. 25 (2010) 1268-1281. https://doi.org/10.1016/j.envsoft.2010.03.007. 